\section{Operation for Hypospadia.}

New York, Jan. 17, 1898.

To the Editor:-Operationes mutantur? This question passes into my mind when I read the notice you give my operation for hypospadias (vide Journal $\mathrm{xxxii,}$ p. 31), after some non-essential modifications were made of it by Bardenheuer as well as by Hacker, in September, 1898.

Of course, occasionally something can escape the argus-eyed editor, and he will, when his attention is called to it, correct the omission. Therefore, I beg leave to direct your attention to the N.Y.Medicinische Monatsschrift for November, 1898, and the N.Y. Medical Journal for Jan. 29, 1898, in which I first published my method of mobilizing and displacing the urethra in correcting the deformity.

While it is far from me to dispute any merit that may be due a German surgeon, I have enough American vanity to ask priority for our country, when deserved, even if $I$ have earned that priority.

Yours sincerely, Carl Beck, M.D.

Higher Rank Desired by the Medical Corps of the Army.

The medical officers of the Army have taken exception to the rank provided for their corps by the terms of the Hull bill, reorganizing and increasing the Army, now before the House in Committee of the Whole. They have addressed the Secretary of War on the subject as a means of bringing their views to the notice of Congress.

War Department : Surgeon-General's Office, ? WAsHiNGTON, Jan. 14, 1899.

To the Honorable Secretary of War, (Through the Adjutant-General of the Army).

Sir:-At a recent meeting of medical officers of the Army, we, the undersigned, were charged as a special committee with the responsibility of gathering the views of the Medical Department in relation to those provisions of H. B. 11022, which have in view the increase of the medical corps and of submitting the said views for your consideration, in the hope that they may meet with your approval and be referred to the Military Committees of the Senate and House of Representatives.

Individually, as members of this special committee, we disclaim any bias from self-interest in considering the subject. We submit the following statement, and urge the adoption of the recommendations herein made, having in view only the efficiency of the Medical Corps of the Army and the best interests of the military service.

At the beginning of the recent war, with a military force of less than 30,000 men, the medical corps consisted of 192 officers, of whom 1 held the rank of brigadier-general ; 6 were colonels; 10 lieutenant-colonels ; 50 majors, and 125 captains and lieutenante, the former grade being reached after five years of eervice in the latter. It will be observed that of this personnel, 3.1 per cent. had the rank of colonel and 5.2 per cent. that of lieutenant-colonel.

We here respectfully eubmit that, although our medical officers at no time made any complaint of having failed to receive from Congress as much consideration as the other staff officers of the Army, they were fully coynizant that, under the existing organization, it was possible for a medical officer to pass his life in active service and to be retired, at 64 years of age, with the rank of lieutenant colonel, or even with that of major. In fact, the last four medical officers who were placed on the retired list at 64 years of age, failed to reach the grade of colonel. Few can expect to become the chief of their corps, but it would seem to be a just expectation for an officer to entertain that after about forty years of service, he should go on the retired list with the highest rank in his corps-outside of the chief. Of the four medical officers recently retired as lieutenant-colonels, one, Lieut.-Col. J. V. D. Middleton, was called upon during the Spanish-American War to do the double duty of Chief Surgeon of the Department of California and Medical Supply Officer on the Pacific Coast, involving the great responsibility of outfitting the expeditions to the Philippine Islands.

In his annual report for the last year, the Surgeon-General recommended an increase of the medical corps as absolutely essential, in view of the increase of the enlisted strength of the Army to a total of $60,000 \mathrm{men}$, and the large number of sta. tions to be garrisoned in the islands acquired and occupied by the United States. He recommended such additions as would give a total personnel of 280 , of whom 8 should have the rank of colonel; 16 of lieutenant colonel and 80 of major, giving percentages respectively of $2,9,5.7$ and 28.5 ; but he entered the proviso that any increase of the Army made by Congress during its coming session would necessitate a further increase of the medical corps.

Action has been taken by Congress in this latter regard. H. B. 11022 has been returned by the Military Committee to the Committee of the Whole House, and its provisions, as relating to the Medical Department, are as follows: 1 surgeongeneral with the rank of brigadier-general; 10 assistant surgeons general with the rank of colonel; 20 deputy surgeonsgeneral with the rank of lieutenant-colonel; 110 surgeons with the rank of major and 360 assistant-surgeons with the rank of captain and lieutenant, amounting to a total of 501 officers, the colonels constituting 2 per cent., the lieutenant colonels 4 per cent. and the majors 22 per cent. of the total.

It will readily be seen that when officers such as Drs. Mid. dleton, Wolverton and Waters have to retire as lieutenantcolonels after a lifetime of service in an organization which has 3.1 per cent. of its members colonels, such retirements would be of more frequent occurrence in the proposed organization, which permits that grade to be held by only 2 per cent. of its members.

The first of the following tabulations presents the absolute numbers of the grades of the various staff corps, as proposed by the Hull bill (H.B. 11022); the second shows the numbers of the various grades as percentages of the totals of each corps :

\begin{tabular}{|c|c|c|c|c|c|c|}
\hline Department. & $\begin{array}{l}\frac{\dot{a}}{0} \\
\frac{0}{0} \\
\dot{b}\end{array}$ & 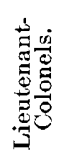 & 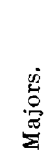 & & 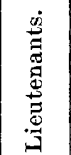 & 要 \\
\hline $\begin{array}{l}\text { Adjutant-General } \\
\text { Inspector-General } \\
\text { Judge Advocate. } \\
\text { Quartermaster's. } \\
\text { Subsistence. } \\
\text { Pay } \\
\text { Engineers. } \\
\text { Ordnance. } \\
\text { Signal Corps. } \\
\text { Medical. }\end{array}$ & $\begin{array}{r}5 \\
4 \\
5 \\
8 \\
4 \\
4 \\
10 \\
6 \\
2 \\
10\end{array}$ & $\begin{array}{r}7 \\
5 \\
4 \\
16 \\
8 \\
8 \\
20 \\
8 \\
3 \\
20\end{array}$ & $\begin{array}{r}11 \\
9 \\
4 \\
25 \\
12 \\
47 \\
36 \\
16 \\
5 \\
110\end{array}$ & $\begin{array}{l}\cdots \\
70 \\
70 \\
37 \\
41 \\
26 \\
12 \\
360\end{array}$ & \begin{tabular}{l|}
$\cdots$ \\
$\therefore$ \\
$\therefore$ \\
50 \\
56 \\
15 \\
$\cdots$
\end{tabular} & $\begin{array}{r}23 \\
18 \\
13 \\
119 \\
61 \\
59 \\
157 \\
82 \\
37 \\
500\end{array}$ \\
\hline All Staff Corps except Medical . . & 48 & 79 & 165 & 277 & $\cdots$ & 569 \\
\hline
\end{tabular}

PERCENTAGES.

\begin{tabular}{|c|c|c|c|c|c|}
\hline Department. & $\begin{array}{l}\frac{0}{0} \\
\stackrel{0}{0} \\
\dot{0}\end{array}$ & 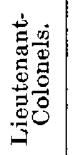 & 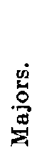 & 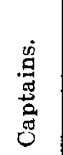 & 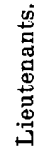 \\
\hline $\begin{array}{l}\text { Adjutant-General.. } \\
\text { Inspector-General. } \\
\text { Judge Advocate. } \\
\text { Quartermaster's } \\
\text { Subsistence... } \\
\text { Pay } \\
\text { Engineers. } \\
\text { Ordnance. } \\
\text { Signal Corps } \\
\text { Medical... }\end{array}$ & $\begin{array}{r}22 \\
22 \\
38 \\
7 \\
6 \\
7 \\
6 \\
7 \\
5 \\
2\end{array}$ & $\begin{array}{r}30 \\
28 \\
31 \\
13 \\
13 \\
13 \\
13 \\
10 \\
8 \\
4\end{array}$ & $\begin{array}{l}48 \\
50 \\
31 \\
21 \\
20 \\
80 \\
23 \\
19 \\
14 \\
22\end{array}$ & $\begin{array}{l}\cdots \\
59 \\
61 \\
61 \\
26 \\
32 \\
32 \\
72\end{array}$ & $\begin{array}{l}\cdots \\
\therefore \\
\therefore \\
32 \\
32 \\
41 \\
\therefore\end{array}$ \\
\hline All Staff Corps except Medical. . . . . . & 8.4 & 13.9 & 29 & 48.7 & . \\
\hline
\end{tabular}

The rank provided by this bill fails to do justice to the medi. cal profession. It is needless to urge here the question of rank for the medical corps. That appears to be allowed and even high rank for a certain number has already been provided. The duties and responsibilities of the Medical Department have been fully brought out by the events of the recent war. The efficiency of the whole army may, under certain conditions, be dependent on the efficiency of the medical corpe. The responsibilities of the corps are as great as those of any of the staff departments. Irrespective of their important duties with troops in the field, the surgeon who has charge of a general hospital containing 1000 sick men, has surely as great responsibility as the colonel of a regiment of 1000 well men, yet during the recent war, the officers in command of general hospitals and hospital ships had, as a rule, only the rank of major. $H$. R. 11022 gives the rank of colonel to only 2 per cent. of the officers of the medical department, while 8.4 per cent. of the other staff corps have this rank. It gives the rank of lieutenant-colonel to 4 per cent. of the medical department and to 
13.9 per cent. of the other staff corps. Medical officers desire their responsibilities to be recognized and to be endowed with as much rank, power and position as officers of corresponding age and experience in the other staff corps. They desire especially that the organization of their corps should have that percentage of the two higher grades, outside of the Chief of the Corps, which would permit every one to look forward to retirement as a colonel after the honest and faithful service of a lifetime.

We, therefore, on behalf of the interests of the medical corpe and their bearing on the efficiency of the Army, recommend that $H$. R. 11022 be amended so as to provide twenty instead of ten assistant surgeons.general, with the rank of colonel, and thirty (insiead of twenty) deputy surgeons general, with the rank of lieutenant-colonel, and to reduce the number of assistant-surgeons, with the rank of captain and lieutenant, from 360 to 340 .

These numbers are not chosen arbitrarily, nor for the mere purpose of reaching a desirable percentage in the higher ranks, for it is easily demonstrated, by a consideration of the duties and positions to which the colonels and lieutenant-colonels should be assigned, that even a large number of such officers would be fully and constantly employed. The assistant to the Surgeon-General, the chiefs of the large and active divisions in his office, the Chief Medical Inspector and his assistants, the Dean of the Army Medical School, the chief surgeons of the numerous home and colonial military departments, the officers commanding the general hospitals of from 500 to 1000 beds, the chief surgeoes of the large garrisons and camps assimilating a brigade organization, and the medical supply officers should all be of these grades, as such duties require officers of trained experience and of rank commensurate with their service and the responsibility of their work.

We would furtber recommend that promotions be made by seniority, after passing the examination required by existing law.

In submitting these recommendations we have in view only the evident and urgent needs of the service, as reorganized on the basis of a total membership of 501. Were we to give full expression to our views of what is desirable and would be ben ficial to the Medical Department and the Army generally, we would urge the consideration and adoption of those provisions of Senate Bill 4900 relating to the Medical Department, which bill is now before the Military Committee of that body. It provides for a corps of 596 officers, comprising 1 surgeon general with the rank of brigadier.general, 20 assistant surgeons general with the rank of colonel, 30 aseistant (deputy?) sur geons-general with the rank of lieutenant-colonel, 175 assistant surgeons-general (surgeons?) with the rank of major, 120 as sistant surgeons general (assistant. surgeons?) with the rank of captain, and 250 assistant surgeons general (assistant-surgeons?) with the rank of lieutenant, mounted. This total of 596 medical officers for an army of 100,000 men is relatively not so large as the medical force now in the service of the United States. The present strength of the regular army is in round numbers 55.000, and of the volunteer army 73,000 men, a total of 128,000 , for whom are provided 892 medical officers, regular, volunteer and contract, or at the rate of one medical man to 144 soldiers. The 596 medical officers of Senate Bill 4900 provides one medical officer to every $168 \mathrm{men}$ of an army of 100,000

We would indeed go further than the said Senate bill when we consider the importance of a Medical Department of an army of 100,000 . Whether it is viewed in the light of medical supply, involving the expenditure of large sums of money, in the light of sanitation, involving the military efficiency of the whole command, in the light of military administration over so many officers, hospital-corps men, nurses and hospital establishments, or in the light of caring for 10,000 men, or 10 per cent. of the Army, which is an average percentage of sick, in times of active service, the importance of the work and the extent of the responsibilities appear to us to be more than equivalent to those of a division commander who has the rank of a major-general. The Chief of the Medical Department in most European armies has this rank. We, therefore, are of the opinion that in recognition of the great responsibilities attaching to the surgeon-generalcy of such an army the officer holding this position should have the rank of major-general and that the senior of the assistant surgeons-general should have the rank of brigadier-general.

$$
\text { Respectfully, }
$$

(Signed) Dallas Bache,

Colonel and Assistant Surgeon-General. (Signed) Ch. SMart,

Lieutenant-Colonel and Deputy Surgeon-General. (Signed) Lours A. LAGARDE,

\section{PUBLIC HEALTH.}

Spain's Losses in Cuba.-An item in a New York daily of January 25 , is to the effect that according to figures published in Madrid, "80,000 Spanish soldiers perished, chiefly from sickness, during the last campaign in Cuba."

Smallpox at Ponce, Porto Rico.-Dr. Monet, Health Officer of Ponce, reports that "Bo far, the smallpox as an epidemic is confined to the native population and is of the confluent variety. An isolated hospital camp is desirable, but both the government and municipality are unable to provide the tents required."

Smallpox Among Zuni Indians.- A Santa Fe, N. M., dispatch of January 25, says that according to late information from the Zuni Pueblo, in the western part of the territory, smallpox is epidemic. The statement is that since the disease broke out 217 deaths have occurred and 600 Indians are ill, of whom possibly one-half will recover. Accounts vary.

Health in Indiana.--Reports from observers in about forty counties, for the week ending January 21 , indicate a decrease in diphtheria, typhoid fever and diarrheal diseases, and indicate a marked increase in la grippe and pneumonia. Fatalities from grip are few. Reports say that a great deal of acute catarrhal inflammation is called grip.

Health in Chicago.- The report of the Board of Health of Chicago for December, 1898, gives the total number of deaths as 1849,348 of which were persons under one year of age, and 220 between one and five years. The death-rate per thousand was 1.14, as compared with 1.10 for December, 1897. The principal causes were: Pneumonia, 282; nervous diseases, 203; consumption, 200 ; heart disease, 133 ; bronchitis, 109 ; acute intestinal diseases, 78; diphtheria and membranous croup, 77 ; cancer, 63 ; typhoid fever, 55 .

Circulars Warning Against the Use of Alcohol.-Legendre has had plainly worded circulars describing the dangers and ravages of alcoholism, hung around the walls of his service in the hospital, and others are imitating his example. He wishes to have popular lectures on the abuse of alcohol delivered before the inmates of the hospitals, and the plan is on the point of realization.-Progres Méd., Dee, 24, 1898.

Guayaquil Not a Health Resort. - According to the Semaine Med., Guayaquil, Ecuador, has no quarantine service, as it is recog. nized that the ports from which the ships arrive can not possibly be unhealthier than Guayaquil itself. The European gov. ernments have found it impossible to keep consuls there, on account of the ravages of yellow fever, and are compelled to engage acclimated residents to serve in that capacity.

Tropon, the New, Cheap Albuminous Food.-Nearly ten pages in the Munich Med. Woch. of January 10 are devoted to a couple of articles describing tests with tropon (vide JounnaL, xxxi, p. 941), confirming in every respect the value of this cheap, nourishing, tasteless preparation, to add to soups, etc. For arctic expeditions, military campaigne, etc., it is particularly valuable on account of its small bulk. It is able to substitute completely the albumin in other foods; causes no disturbances; can be taken for long periods without aversion, and costs only four marks a kilogram, much cheaper than meat.

Propagation of Bubonic Plague.-We note in Simond's comprehensive study of the plague (Annales de l'Institut Pasteur, October, 1898), that the flea is the means by which the plague is transmitted. The germ thrives in the alimentary canal of the flea and is then inoculated into the rat or man the flea alights on. A temperature of 70 degrees C., for several hours, suffices for disinfection, and protective measures against fleas and rats and persons arriving from infected localities, with prophylactive serum injections, he considers would reduce the number of cases to the minimum. 